\title{
Expected Versus Real Effects and Challenges of Urbanization in Albania During the Transition: A Focus Group-Based Assessment
}

\author{
Myslym Osmani, PhD \\ Department of Agricultural Economics and Rural Development Policies, \\ Agricultural University of Tirana, Tirana, Albania \\ Mustafa Ergen, PhD \\ Department of Architecture, Faculty of Fine Arts and Design, \\ Siirt University, Siirt, Turkey
}

URL:http://dx.doi.org/10.19044/esj.2019.v15n25p79

\begin{abstract}
This paper focuses on learning about the characteristics, effects, and challenges of the urbanization in Albania during transition. Key research point involves assessing how much effective urbanization was. Focus group discussion was the research method used. Major findings about the urbanization in Albania are: an unplanned process, weak and incomplete legislation, weak public management capacities, conflict, and widespread informality. Reduction of poverty and unemployment are positive effects, but a significant gap exists between expected and real effects ( -4 and -3.9 , for employment and poverty). Disappointing is an effect on education quality and climate for private business activities. In general, negative effects out-passed significantly the expected ones by 2.6 points. Major negative effects are increased crime, congestion and pollution, reduced green area, loss of family bonds, and some loss of traditions and rural values. Major challenges in the future include efficient management of land, improving quality of education, reduction of informality and illegal economic activity, and guaranteeing land property rights. In conclusion, urbanization in Albania was a deficient process. This is with positive effects and also with harsh negative consequences and tough challenges ahead. Managerial and policy recommendations, and propositions for further research, are provided at the end of the study.
\end{abstract}

Keywords: Migration, Urbanization, Informality, Poverty, Pollution

\section{Introduction}

Albania is a country located in Southeast Europe with a population, as of year 2017, of about 2.87 million. From 1944 to 1990, Albania was ruled by 
a communist regime. People lived in poverty, as the GDP per head was only 936 US dollars (Lerch, 2016). In 1991, Albania joined other South-East European countries in their path to democracy.

Under communism, the movement of people from rural areas to cities was prohibited, and it was rare and very selective when it happened. After the fall of communism, free movement of people was allowed, with considerable flows of people leaving their home country or moving from rural areas to urban ones (MIA et al., 2017). Actually, mostly due to internal rural-to-urban migration, about $59.4 \%$ of the population is urban and the rest is rural with $35.5 \%$ in 1989 and $42.1 \%$ in 2001 (INSTAT, 2019b; Statista, 2019).

Generally, researchers and institutions concerned with migration and urbanization in Albania agree about the characteristics of the process dynamics. Migration (and urbanization) developed in three phases: 19911995, 1996-2001, and 2001-2013. Anarchy and moving of poor people from rural and periphery areas to main economic centers (Tirana, Durres) characterized the first phase. A major feature of this phase was the dominance of the informal sector. Due to its destructive character, the urbanization process in Albania in this phase sometimes is called "urban massacre" (Pojani, 2009).

The second phase began with the collapse of pyramid schemes (1997) and loss of savings of the population. In this phase, the informal sector gained strength and the formal sector appeared. Thus, political stability, stronger economic growth, and strengthening of the formal sector characterized the third phase (WB, 2007; Lerch, 2016). Efforts were made in this phase for the legalization and integration of immovable property market (WB, 2007). Both the first and second phase has been more or less out of control.

To our opinion, there is also the fourth phase of urbanization, beginning in the year 2013 and continuing so far. In this phase, efforts to improve legislation and bring informality under control was the major characteristics. During this fourth phase, a new territorial reform was carried out, resulting in 61 bigger communes from 373 of before reform. In 2015, the government developed the first National Spatial Plan. The government also has approved a territorial planning regulation which sets out unified rules for the structure, content, and steps of designing, implementing, and monitoring the implementation of territorial adjustment plans (CM, 2017).

\section{Research Problem}

As literature highlights (King \& Vullnetari, 2003), urbanization as a process remains under-researched. A fuller identification of the array of reasons, effects, and challenges are too far from being complete. Also, a prioritization of what is most important in terms of characteristics, reasons for migration, effects, and challenges of the urbanization process in Albania is 
still not well determined. This study seeks to add knowledge and information about the above issues, what is at the same time the research problem at hand.

\section{Research Goal}

This study aims at adding knowledge and information about urbanization characteristics, reasons, effects, and challenges that people and governing bodies in Albania are facing today.

\section{Research Questions}

What are the most salient features of the urbanization happening in the transition process of Albania? What are the most important reasons for ruralto-urban migration? What are the expected and real effects, positive and negative, of urbanization and the gap between them? What major challenges by priority are people facing and public governing agencies as of today? How effective is the management of the process? How effective is the urbanization in Albania in reaching its goals?

\section{Literature Review}

Urbanization is the process of "becoming more like a city" (CALDT, 2019). Louis Wirth states that urbanization is a way of life; it is the urban mode of life but it cannot be confined to cities only (Wirth, 1938). Thus, when speaking about urbanization, one should bear in mind also about the change in the lifestyle of the people. Information in regard to what is happening with the rural people having migrated to cities should also be obtained, i.e., how much civilized they are or they have become. Urbanization could also be termed as a spatial transformation with people relocating from rural to urban areas (Christiaensen \& Todo, 2013).

Literature highlights that there is a correlation between urbanization and economic development. Nevertheless, there are some debate behind this. Consequently, there is a significant relationship between urbanization and economic development as growth in terms of income per head is more acceptable, but it is less clear if we mean economic development growth income (Pole'se, 2005). The reason behind this relationship is higher productivity in urban areas because non-agricultural firms usually run.

Urbanization generates economic development and employment given economies of scale and agglomeration (World Bank, 2009). Thus, the potential of urbanization to promote growth depends on supportive policies, markets and infrastructure investments, public infrastructure, and implementing supportive land policies (Turok \& McGranahan, 2013).

Many researchers have made efforts to check empirically the relationship between urbanization and economic growth (Tolley \& Thomas, 1987; Solarin \& Shahbaz, 2013). 
On the other side, the economic development of a country has an impact on urbanization (Lerch, 2016). This happens because, as Christiansen and Todo (2013) highlight, development is accompanied by an occupational shift towards more productive non-farm activities in urban areas. They show also that migration out of farming into the rural nonfarm sector and secondary towns yields more inclusive growth patterns and faster poverty reduction than agglomeration in mega cities.

The major reasons for rural-to-urban migration in Albania, hence urbanization, still remains unemployment among the young generation, in particular, and poverty in rural areas after the fall of communism (MIA et al., 2017). In cities, it is much cheaper to provide basic services, and economies of scale in the cities bring economic opportunities and also increase people's income (Andersen, 2002). Other positive effects of the urbanization could also be mentioned, such as the transformation of the characteristics of the ruraltraditional population into contemporary urban, socialization of the population, etc. (UN, 2019).

Thus, movement of people from impoverished and resource-less mountainous rural areas toward cities near the Adriatic Sea was a necessary step in the economic development of Albania. In addition, the formalization of the informal real estate sector was and still remains a major challenge (Bertaud, 2006).

One of the effects of the migration from rural areas has been the exceptional population growth rate in places of destination, such as the TiranaDurres corridor (King \& Vullnetari, 2003). Thus, this area has become a place of new and creative enterprises, major labor market, and possibilities for the exchange of new ideas (World Bank, 2007).

The period with the greatest population growth, mainly due to migration, is that between the years 1993 and 2000. Later, migration flows reduced to $31.3 \%$ between 2001 and 2008, and to $10-12 \%$ between the years 2008 and 2013 (Sulaj \& Themelko, 2015). Thus, there is still a continious migration rate but at a slower pace. The highway built along this corridor improved employment as well because of fast business and commercial development.

As research shows, the costs of urbanization that people are generally worried about include increased crime, increased pollution, congestion, loosening of family bonds, and loss of traditional cultural practices and values (Andersen, 2002). Urbanization was also associated with a reduction of green area (Sulaj et al., 2015). Tirana city, in particular, experienced serious environmental degradation. For example, the content of solid particles (LNP of PM10) in the air of Tirana city in 2013 was exceeded by 2 to 4.5 times the EU standards (Tase \& Xhaferri, 2015). 
The brain drain because of migration has also created a high differentiation in capacities between the "center" and the "periphery" (Janku et al., 2017).

Rapid urbanization in Albania was not accompanied by enough and adequate intervention in the public networks. Urbanization in Albania is characterized by "informality and absence of planning" (Janku et al., 2017). Also, legislation in force and legal initiatives to improve it, before the year 2013 in particular, has been insufficient (MUDV, 2014).

Use of SDIs (Spatial Development Instruments) and a national spatial plan for the effective governance of and sustainable large urban areas is considered to be indispensable (Potsiou et al., 2010; Janku et al., 2017). The use of modern techniques such as multi-criteria decision analysis and geographic information system (GIS) are also considered to be powerful analytical tools for mapping suitable locations for urban development. This is more critical for countries and cities where there is limited suitable space for urban development (Ergen \& Ergen, 2016). Hierarchical cluster analysis to check patterns of land use can also give interesting results and contribute to the sustainable development of cities (Ergen \& Ergen, 2019).

\section{Data and Method}

Primary data are collected through group discussions. Secondary data, about unemployment and poverty levels, are also collected from trustable sources, such as INSTAT (Institute of Statistics of Albania) to clarify things and make comparisons with results obtained from primary data.

An expert-based evaluation approach has been used. To do so, at the beginning of the evaluation, a group of experts were formed. The group was composed of development and agricultural economists, rural development economists, agronomists and ecologists, sociologists, and urban planners. The task of the group was based on their experience, information, and opinions to assess as fully as possible and make the evaluation of the characteristics, effects (both positive and negative), as well as major challenges ahead for the solution of problems that arose during the process of urbanization. Group discussion was the method used to generate and confront various potential ideas, generate data, and make the evaluation. Scoring was the tool used to make evaluations characteristics, effects, and challenges in a quantitative way along a Likert scale from 0 to 10 . The evaluation proceeded through some sessions.

In the first session, the group made the evaluation of major characteristics of rural-to-urban migration and resulting urbanization. Each member was asked the question: What were the major characteristics of the urbanization in Albania according to your opinion? Each member responded individually and independently, and a summary of the answers was made 
based on the group discussed and agreed upon on the major characteristics. After that, the Likert scale was used by each of the group members to evaluate the characteristics. After data processing, an average score was calculated for each characteristic.

In the second session, the group identified and evaluated the reasons behind rural-to-urban migration using the same procedure, by asking the question: What are the major reasons for rural-to-urban migration in Albania after the nineties? This session produced a list of reasons for urbanization and an average score for each of them.

In the third session, the group identified and evaluated the expected and the real effects produced by the urbanization using the same procedure, by asking the question: What are major expected and real positive results or effects of urbanization in Albania after the nineties? This session produced a list of expected and real positive effects of urbanization and an average score for each of them.

The fourth session, using the same procedure, produced a list of major negative effects of urbanization and an average score for each of them. The question used was: What are the major expected and real negative results or effects of urbanization in Albania after the nineties? This session produced a number of expected and real negative effects of urbanization and an average score for each of them.

The last session was to in-group identification and evaluation of major challenges to successfully cope with the negative effects of the urbanization process. The procedure was the same, and the question for each group member was: What are the major challenges on the way to cope with the negative effects of the urbanization? This session produced a list of major challenges together with an evaluation average score for each of them.

\section{Results and Discussion}

Table 1 shows a summary of urbanization features and their evaluation scores. As in the case of effects and challenges, the evaluation scores are group averages and is for the entire time span from 1991 to 2016 in general. The chaotic/uncontrolled character of urbanization, together with lack of policies to discourage emigration, weak relevant legislation and its implementation, as well as mismanagement of land and other resources have been the major features of the urbanization process. The conflicting character has also been evaluated highly as very crucial. Being so highly evaluated, these are the major determinants of the whole pattern of effects, both positive and negative, of the urbanization in Albania. Other features have potentially played an indirect role in encouraging migration to cities, such as no direct support to rural non-farm activities and insufficient support to rural infrastructure. 
Table 1.Features of the urbanization process

\begin{tabular}{lc}
\hline Features of the process & Score \\
\hline It was a chaotic/uncontrolled process & 10 \\
No policy to discourage migration & 9.5 \\
Conflicting, because of illegal capture of land & 9.3 \\
Mismanagement or destruction of land and other resources & 8.5 \\
Ineffective-failing to achieve goals & 7.5 \\
Concentrated in central or western zones & 7.5 \\
Eruptive & 8.2 \\
Combined (International migration with internal, & 8.1 \\
rural-to-urban with rural to rural) & \\
Weak capacity within local or central power to: & 9.1 \\
(Create public infrastructure in urbanized areas, & \\
supply/support water, energy, educational, & \\
medical services in urbanized areas) & \\
Weak specific legislation & 9.2 \\
Weak implementation of the legislation & 9.5 \\
Missing proper land policy & 7.5 \\
No specific support to rural non-farm business & 8.5 \\
No direct support to rural farm activities & 7.1 \\
Insufficient support to agricultural infrastructure & 8.2 \\
Poor information creation and transmission about the process & 6.5 \\
Weak real estate market & 8.6 \\
\hline
\end{tabular}

Source: Group discussion

Weak real estate market, weak urbanization-related legislation as a characteristic of the process, weak local management capacities, the chaotic character of urbanization, and lack of planning are all in line with literature findings (MUDV, 2014; WB, 2007; Andersen, 200; Janku et al., 2017).

Table 2 presents an array of reasons for migration as shown from the expert-based group discussion.

\begin{tabular}{lc}
\multicolumn{2}{c}{ Table 2.Reasons for migration/urbanization } \\
\hline \multicolumn{1}{c}{ Reasons for migration } & Score \\
\hline Poverty & 10.0 \\
Unemployment & 8.3 \\
Poor education of children & 9.2 \\
Lack of potable water supply & 7.5 \\
Lack of electricity & 6.8 \\
Rural land degradation & 7.5 \\
Poor housing & 6.5 \\
Poor access to health services & 9.5 \\
Living insecurity & 8.5 \\
No recreation opportunities & 5.8 \\
\hline
\end{tabular}

Source: Group discussion

Based on the evaluation scores, reasons for urbanization provide a strong justification base for the rural people to migrate from rural-to-urban areas due to poverty and, it might be paradoxical, poor education of children. 
However, poor basic health services seem to be the strongest reasons for migration. Unemployment follows as another important reason for migration, resulting to urbanization. Findings in respect to the reasons for migration to cities are in conformity with findings from the literature. Unemployment and poor economic situation reason for migration have been highlighted by many researchers (WB, 2009; MIA et al., 2017; Sulaj et al., 2015; Andersen, 2002). Findings about the poverty level of people and poor basic services as reasons for migration are in conformity with findings from literature (Andersen, 2002). Table 3 shows the expected and real positive effects identified by the group and average evaluation results for each of them.

Table 3-Positive effects for the urbanized areas

\begin{tabular}{lccc}
\hline Positive effects & \multicolumn{2}{c}{ Expected } & Gap \\
& versus real effects & (Real- \\
& Expected & Real & expected) \\
\hline Reduction of poverty & 9.5 & 5.6 & -3.9 \\
Employment & 8.2 & 4.2 & -4 \\
Education quality & 9.3 & 4.7 & -4.6 \\
Water supply & 8.4 & 5.2 & -3.2 \\
Power supply & 8.5 & 5.3 & -3.2 \\
Opportunities for recreation & 6.5 & 5 & -1.5 \\
Socialization & 5.5 & 3.1 & -2.4 \\
Housing & 7.5 & 7.3 & -0.2 \\
Health services & 8.7 & 4.8 & -3.9 \\
Specialization of people & 6.8 & 4.4 & -2.4 \\
Transformation of rural culture/values & 7.8 & 5.5 & -2.3 \\
Land use efficiency & 9.5 & 8.5 & -1 \\
Private business activity & 9.3 & 5.2 & -4.1 \\
Location stability & 8.7 & 5.8 & -2.9 \\
Life security & 8.8 & 5.6 & -3.2 \\
Diversity of cultures & 9.2 & 8.8 & -0.4 \\
\hline Average score & 8.3 & -2.7 \\
\hline & Source: Group discussion
\end{tabular}

In general, there has been a high expectation among people based on positive results of migration and urbanization (average score of 8.3). Among the highest are expectations about the reduction of poverty, land use, business opportunities, and land-use changes. Real effects are perceived at much lower levels (average 5.6) and the difference between expected and real effects are considerable ( -2.7 on the average). Thus, what has been in fact achieved through urbanization is almost $30 \%$ lower than expected; this could be considered a significant gap.

Particular disappointing have been effects about education quality (4.6), climate for private business activities (-4.1), and employment and reduction of poverty (respectfully -4 and -3.9 ). Compared to the reasons for migration, there is a good association between evaluation scores for such reasons (education, poverty, health services, living security and employment) 
as far as expected results are concerned. Literature also highlights the positive role of urbanization towards poverty reduction and improved employment (WB, 2007; WB, 2009; Andersen, 2002). Secondary data also show a reduction, though with some variation over the years (Figure 1).

Figure 1.Headcount as poverty measure in Albania

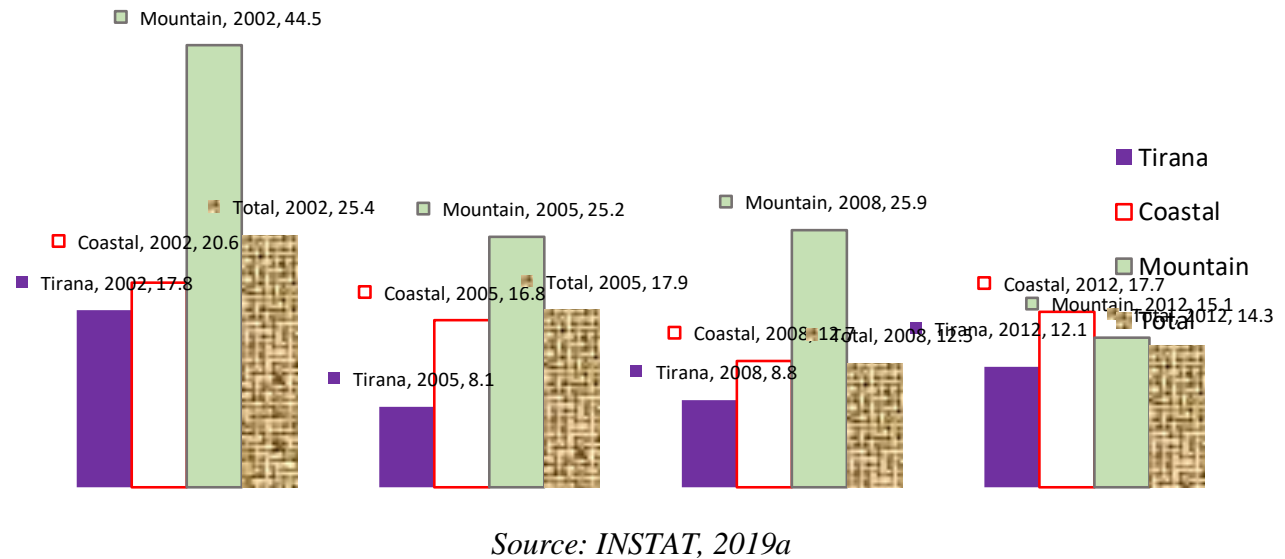

The headcount as a poverty measure for the country in general and for different regions and Tirana city has been declining, with some increase for the coastal zone and Tirana in the year 2012.

Regarding the issue of employment, data show a general trend of decrease over the years, with some ups and downs for selected years. The highest level of unemployment rate $(22.3 \%)$ has been observed in the year 1993, that is two years after the collapse of the communist regime and the beginning of the eruptive rural to urban migration. The lowest level of the period before the year 2000 has been recorded in the year 1996 (12.4\%), while the lowest level ever recorded $(12.1 \%)$ refers to the first quarter of the year 2019 (ODA, 2019; INSTAT, 2019b).

The following Table 4 shows expected or real negative effects identified by the group and average evaluation scores for each of them. As figures show, people perceive much more than expected negative effects (average score 6).

Results about informal business and employment have resulted in particularly high (scores 9.7 and 9.2), followed by acoustic pollution, waste and congestion, illegal construction and tenure insecurity, not to forget reduction of green areas, heavy traffic, and creation of slum-like informal zones. 
Table 4.Negative effects for the urbanized areas

\begin{tabular}{lccc}
\hline Negative effects & \multicolumn{2}{c}{$\begin{array}{c}\text { Expected } \\
\text { versus real effects }\end{array}$} & $\begin{array}{c}\text { Gap } \\
\text { (Real- }\end{array}$ \\
& Expected & Real & expected) \\
\hline Increased crime & 6.5 & 9.2 & 2.7 \\
Land property conflicts & 6.5 & 9.2 & 2.7 \\
Heavy traffic & 6.5 & 8.3 & 1.8 \\
Land pollution & 4.5 & 6.9 & 2.4 \\
Air pollution & 5.5 & 8.3 & 2.8 \\
Congestion & 6.4 & 9.6 & 3.2 \\
Waste creation & 7.5 & 9.8 & 2.3 \\
Insufficient water supply & 5.3 & 8.6 & 3.3 \\
Poor quality of potable water & 5.5 & 7.8 & 2.3 \\
Higher pressure on land & 5.5 & 8.2 & 2.7 \\
Acoustic pollution & 7.7 & 9.3 & 1.6 \\
Tenure insecurity & 6.8 & 9.0 & 2.2 \\
Illegal construction & 5.5 & 9.5 & 4 \\
Reduction of population growth rate & 8.3 & 8.9 & 0.6 \\
Loosing family bonds & 5.5 & 6.1 & 0.6 \\
Brain drain in rural areas & 5.8 & 8.2 & 2.4 \\
Difference in capacities between rural & 6.8 & 7.2 & \\
and urban population & & & 0.4 \\
Reduction of green area & 6.8 & 8.9 & 2.1 \\
Informal business & 5.5 & 9.7 & 4.2 \\
Informal employment & 4.8 & 9.2 & 4.4 \\
Informal zones & 4.3 & 8.3 & 4 \\
Deterioration of urban standards & 4.8 & 7.9 & 3.1 \\
\hline Average score & 6.0 & 8.6 & 2.6 \\
\hline
\end{tabular}

Source: Group discussion

Much more negative effects than expected are those in relation with all kinds of informality and illegal construction. This is followed by insufficient potable water and deteriorated urban standards, congestion, increased crime, and land property conflicts. In summary, the negative effects of urbanization have been about $26 \%$ higher than expected.

Some of the major negative effects such as crime, pollution, reduced green area, and congestion mentioned by the literature (UN, 2012; Potsiou, 2012; Sulaj \& Themelko, 2015; Sulaj et al. 2015; Tase \& Xhaferri, 2015) are in line with findings from our research. In general, there have been much more negative effects than expected because the estimated gap is significant (2.6 points above expected aggregate level).

The following Table 5 shows the identified challenges by the group of experts and the average evaluation scores for each of them.

Although law and regulation for the regulation of the territory are already in place, the toughest challenge seems to be efficient management of the territory. This is together with improving the quality of education and 
reduction of informality and illegal economic activity. Guaranteeing land property rights and tenure security are also crucial challenges.

Table 5. Challenges for the urbanized areas

\begin{tabular}{lcc}
\hline Future challenges & Score & $\begin{array}{c}\text { Challenge } \\
\text { rank }\end{array}$ \\
\hline Efficient management of territory & 9.6 & 1 \\
Improve quality of education & 9.6 & 2 \\
Reduction of informal and illegal business & 9.6 & 3 \\
Formalization of illegal construction & 9.4 & 4 \\
Expand business opportunities & 9.3 & 5 \\
Land property rights & 9.2 & 6 \\
Improve business climate & 8.8 & 7 \\
Improve employment opportunities & 8.7 & 8 \\
Guarantee tenure security & 8.5 & 9 \\
Reduction of informal employment & 8.5 & 10 \\
Improve public health service & 8.1 & 11 \\
Building local power capacities & 7.5 & 12 \\
Reduce pollution & 6.8 & 13 \\
Guarantee investment sources for local power & 6.5 & 14 \\
Improve public transportation & 4.3 & 15 \\
\hline
\end{tabular}

Source: Group discussion

Improving employment and health services for the population seem also arduous to achieve. An indicator for the challenge of employment could be a revitalization of out-ward migration of the people over the last 5 to 7 years. This is to say that lately flows of international migration have increased, being similar to those of the nineties. Literature as well points out some major challenges, such as strengthening capacities within local authorities (WB, 2007), formalization of the informal sector (Bertaud, 2006), quality of education (UN, 2019; WB, 2007), and reduction of crime, pollution, dust, noise, traffic and congestion (WB, 2007; Tase \& Xhaferri, 2015).

\section{Conclusions and Recommendations}

\section{Conclusions}

Urbanization in Albania, as elsewhere, has been and still continues as an objective process. It is not just the increase in the share of the urban population, but a way of life. Though extensive literature exists about how the process of urbanization in the world and in Albania happened and is happening, and the effects of this process, there is much more to learn about it.

The aim of this research was to learn about the characteristics, expected and achieved effects of the urbanization in Albania during the transition, as well challenges, negative consequences or problems that are particularly difficult to manage in the future. Key research point aims to assess how much effective urbanization was. This is achieved by comparing expected 
real effects, evaluating the gap between them, and assessing how effective the management of the process was. Study of the literature, focus group discussion, and use of secondary data were the methods used to achieve the research objectives.

Urbanization in Albania was spontaneous, chaotic, uncontrolled, and unplanned. Legislation about urbanization has been weak and incomplete, though significant improvements have been made after the year 2013 with a new law on the planning of territory and creation of enforcement agencies. Capacities of both central and local power to manage and support urbanization or its consequences have been weak and insufficient though with some trend of improvement. It also brought about significant conflict between ex-owners of land and newly settled dwellers in the urbanizing zones. Informal business and employment have been other major characteristics of the urbanization in Albania. Furthermore, weak support for rural farm and non-farm activities and infrastructure has been provided throughout the period. This, therefore, is with some improvement after the year 2006 with rural infrastructural projects and direct support for the farm business.

Reduction of poverty and unemployment rates have been among the positive effects of the urbanization, which is a significant gap that exists between the expected and real effects ( -4 and -3.9 respectfully for employment and poverty). Disappointing could be considered effects about education quality (-4.6) and climate for private business activities (-4.1).

Negative effects have been following or caused by urbanization. Among major ones are increased crime, pollution, reduced green area, congestion, loss of family bonds, and loss of traditions and rural values. In general, negative effects out-passed expected as the estimated gap is significant (2.6 points above expected aggregate level).

Major challenges in the future are efficient management of land, improving the quality of education, reduction of informality and illegal economic activity, guaranteeing land property rights, improving employment and health, strengthening of capacities within local authorities, formalization of the informal sector, and reduction of crime and pollution.

In conclusion, urbanization in Albania, if it does not fail, is a deficient process with important positive effects and harsh negative consequences.

\section{Recommendations}

The use of Spatial Development Instruments and design of a national spatial plan would be important tools for effective governance of urban areas. Urban development plans and projects should keep in mind and allow for the effective use of public transport. Modern techniques and geographic information system must be used as a mapping tool for urban development, in particular, when there is a limited suitable space for urban development. 
Hierarchical cluster analysis to examine patterns of land use is also recommended to obtain good and acceptable results in urban development. While developing cities, sustainable development needs planned and balanced distribution of social infrastructure in urban development plans.

\section{Scope for Further Research and Limitations of the Study}

This research is wide and general in its scope. Many topics and aspects of the research problems need further and more in-depth study. Thus, it would be interesting to learn how traditional or cultural values of the population have been changing during urbanization. This involves a large scale survey-based study from the migrant people perspective in order to evaluate the same issues as in the actual study according to regions, educational, gender, etc. The role played by women during rural-to-urban migration and urbanization would be another topic.

Finally, the results of the study is based mainly on expert evaluation. As a result, they reflect the perceptions, opinions, and experiences of the group. As such, a certain degree of bias is inevitable. Another survey-based study could yield more consistent results.

\section{References:}

1. Andersen, L. E. (2002). Rural-urban migration in Bolivia: Advantages and disadvantages, Documento de Trabajo, No. 05/02, Universidad Católica Boliviana, Instituto de Investigaciones Socio-Económicas (IISEC), La Paz. Available at: http://hdl.handle.net/10419/72834

2. Bertaud, A. (2006). Urban development in Albania: the success story of the informal sector. Available at: http://alainbertaud.com/wpcontent/uploads/2013/06/AB_Albania-Urban-informal-Sectorpaper.pdf

3. CALDT-Cambridge Advanced Learners' Dictionary\& Thesaurus, (2019). Available at: https://dictionary.cambridge.org/dictionary/english/

4. Christiaensen, L. \& Todo, Y. (2013). Poverty Reduction during the Rural-Urban Transformation, Policy Research Working Paper Series 6445, the World Bank. Available at: https://ideas.repec.org/p/wbk/wbrwps/6445.html

5. CM (Council of Ministers of Albania) (2017). Decision No. 686, For the Approval of the Regulation for Planning of Territory, dated 22.11.2017, Official notebook, Year 2017, No. 211. Available at: http://extwprlegs1.fao.org/docs/pdf/alb176103.pdf

6. Ergen Y. B. \& Ergen, M, (2016). Using multi-criteria evaluation to determine suitable land use areas in costal zones. Case of Study of Zonguldag City, Turkey, Journal of Environmental Protection and 
Ecology, 17, No 3, 1105-1110. Available at: JEPE_book3_2016_1105-1110\%20(1).pdf

7. Ergen, M. \& Ergen, Y. B. (2019). An examination of land use in the Amasya development plan through cluster analysis, Applied Ecology and Environment Research, 17(4):9651-9668. Available at: http://www.aloki.hu ISSN 15891623 (Print) ISSN 17850037 (Online), DOI: http://dx.doi.org/10.15666/aeer/1704_96519668

8. INSTAT, (2019a). Poverty measures by regions. Available at: http://databaza.instat.gov.al/pxweb/sq/DST/START__LSMS/LSMS0 1/?rxid=87b6d4d0-aa74-438b-9a3a-90f6ab2e73f8

9. INSTAT, (2019b): Key information. Available at: http://www.instat.gov.al/al/home.aspx

10. Janku, E., Allkja, L. \& Aliaj, B. (2017). Albania 2030 Manifesto, an Example for Adapting Advanced National Spatial Planning Instruments for Developing Countries, Universal Journal of Management 5(7): 320-331, 2017 http://www.hrpub.org DOI: 10.13189/ujm.2017.050702

11. King, R. \& Vullnetari, J. (2003). Migration and Development in Albania Working Paper C5, Sussex Centre for Migration Research, Issued by the Development Research Centre on Migration, Globalization and Poverty. Available at: http://www.sussex.ac.uk/Units/SCMR/drc/publications/working_pap ers/WP-C5.pdf

12. Lerch, M. (2016). Internal and International migration across the urban hierarchy in Albania, Popul Res Policy Rev (2016) 35:851-876. DOI 10.1007/s11113-016-9404-2. https://link.springer.com/article/10.1007/s11113-016-9404-2

13. MIA-Ministry of Internal Affairs of Albania, Ministry of Social Welfare and Youth, INSTAT, Bank of Albania \& National Business Centre, (2017). Migration profile 2016 Republic of Albania. Available at: https://mb.gov.al/wpcontent/uploads/2018/02/Profili_i_Migracionit_2016_Eng.pdf

14. MUDV (Ministry of Urban Development and Tourism of Albania), (2014). Document of Policies for Planning and Development of Territory in Albania. Available at: http://infrastruktura.gov.al/wpcontent/uploads/2017/10/DOKUMENTI_I_POLITIKAVE_TE_PLA NIFIKIMIT_DHE_ZHVILLIMIT_TE_TERRITORIT.pdf

15. ODA-Opendata Albania, (2019). Available at: http://open.data.al/sq/lajme/lajm/lang/sq/id/144/Shkalla-ePapunesise-Historike-ne-Shqiperi

16. Pojani, D. (2009). Urbanization of Post-communist Albania: Economic, Social, and Environmental Challenges, Journal of 
Contemporary Central and Eastern Europe. Available at: http://www.tandfonline.com/10.1080/09651560902778394,DOI: 10.1080/09651560902778394

17. Pole`se, M. (2005). Cities and National Economic Growth: A Reappraisal, Urban Studies, Vol. 42, No. 8, 1429-1451, July 2005

18. Potsiou, Ch. (edit.), Doytsher, P. Kelly, R. Khouri, R. Mclaren \& H. Mueller (2010). Rapid Urbanization and Mega Cities: The Need for Spatial Information Management. Available at: https://www.fig.net/resources/monthly_articles/2010/march_2010/ma rch_2010_potsiou_etal.pdf

19. Solarin, S. A. \& Shahbaz, M. (2013). Trivariate Causality between Economic Growth, Urbanization and Electricity Consumption in Angola: Co integration and Causality Analysis, MPRA Paper No. 45580, Munich Personal RePEc Archive. Available at: http://mpra.ub.uni-muenchen.de/45580/

20. Statista (2019). Urbanization in Albania. Available at: https://www.statista.com/statistics/444566/urbanization-in-albania/

21. Sulaj, A. \& Themelko, H. (2015). Impact of Urbanization to Demographic Changes Occurred in Recent Years in Areas along the Tirana-Durres Corridor, Anglisticum Journal (IJLLIS), Volume: 4 | Issue: 1, January 2015, pp 43-46

22. Sulaj, A., Themelko, H. \& Shumeli, A. (2015). Land use change in the Corridor Tirana-Durres caused by urban development, in Albanian Journal of Agricultural Sciences, 2015;14 (2): 87-92

23. Tase, M. \& Xhaferri, M. (2015). Urban Development of Tirana after 90 years and its Environmental Problems, Proceedings of REHVA Annual Conference 2015 "Advanced HVAC and Natural Gas Technologies" Riga, Latvia, May 6 - 9, 2015

24. Tolley, G. S. \& Thomas, V. (1987). An overview of urban growth: problems, policies and evaluation. The Economics of Urbanization and Urban Policies in Developing Countries, Washington DC: The World Bank, 15-31. Available at: https://pdfs.semanticscholar.org/a98c/53fe3eb1aa85cd278e458d83ea 2a6eca3d37.pdf

25. Turok, I. \& McGranahan, G. (2013). Urbanization and economic growth: the arguments and evidence for Africa and Asia, in Environment \& Urbanization Volume 25(2): 465-482. DOI: $10.1177 / 0956247813490908$

26. UN (2019). World Population Prospects: Albania Population 2019. Available at: http://worldpopulationreview.com/countries/albania/

27. Wirth, L. (1938). Urbanism as a Way of Life Author(s), The American Journal of Sociology, Vol. 44, No. 1 (Jul., 1938), pp. 1-24 
28. Woorld Bank (2007). Albania Urban Sector Review, Sustainable Development Department Europe and Central Asia Region, Report No. http://documents.worldbank.org/curated/en/125501467992047283/pd f/372770ENGLISH01iew 1P09932501PUBLIC1.pdf

29. World Bank (2009). World Development Report 2009: Reshaping Economic Geography, World Bank: Washington D.C. Available at: http://documents. worldbank.org/curated/en/730971468139804495/pd f/437380REVISED01BLIC1097808213760720.pdf 